REPORTS OF MORPHOLOGY
Official Journal of the Scientific Society of Anatomists,
Histologists, Embryologists and Topographic Anatomists
of Ukraine
journal homepage: https://morphology-journal.com

\title{
Ultrastructural organization of hemomicrocirculatory bed of the lungs affected by Doxorubicin
}

\author{
Zaiats L.M. ${ }^{1}$, Yankiv O.O. ${ }^{2}$, Gunas I.V. ${ }^{2}$, Shapoval O.M. ${ }^{2}$, Shypitsina O.V. ${ }^{2}$
}

${ }_{1}^{1}$ vano-Frankivsk National Medical University, Ivano-Frankivsk, Ukraine

${ }^{2}$ National Pirogov Memorial Medical University, Vinnytsya, Ukraine

\section{ARTICLE INFO}

Received: 9 July, 2019

Accepted: 21 August, 2019

UDC: $616.24+0616-092.9+615.33$

\section{CORRESPONDING AUTHOR}

e-mail: patfisiology@ifnmu.edu.ua Zaiats L.M.
One of the most effective anticancer drugs for breast cancer, lymphoma, soft tissue sarcoma, leukemia, some solid tumors is Doxorubicin. However, its antitumor effect directly correlates with the dose-dependent manifestation of toxicity to healthy tissues and body systems. The purpose of the study is to study the dynamics of ultrastructural changes of the hemomicrocirculatory bed under the influence of Doxorubicin. Animals were divided into 3 groups: I - intact rats $(n=10)$; II - control $(n=20)$; III - rats with Doxorubicin model $(n=40)$. Doxorubicin was administered intraperitoneally at a dose of $5 \mathrm{mg} / \mathrm{kg}$ body weight once a week for 4 weeks. An animal control group was intraperitoneally injected with an equivalent volume of saline. Pulmonary tissue sampling for electron microscopic examination was performed under thiopental anesthesia 7 , 14, 21, 28 days after the start of the experiment. Pieces of pulmonary tissue were fixed in $2.5 \%$ glutaraldehyde followed by fixation in $1 \%$ osmium tetroxide. After dehydration, the material was poured into araldite-epon. The sections obtained on a "Tesla BS-490" ultramicrotome were examined in an electron microscope "PEM-125K". It is established that within 7 days after the first injection of Doxorubicin in the lungs changes in the structural organization of the hemomicrocapillary bed and the disturbance of blood rheological properties are determined, as evidenced by the excessive accumulation of neutrophils in the hemocapillaries, their adhesion and aggregation. With the extension of the study period (14-28 days) there is a progressive disturbance of the submicroscopic structure of hemocapillaries of the alveolar wall and marked changes in the rheological properties of blood. In endothelial cells, swelling phenomena with organelle disorganization are determined, and in some areas there is a desquamation of endothelial cells into the lumen of the hemocapillaries with basal membrane exposures. In the lumen of the microvessels, red blood cells and leuco-platelet aggregates are noted. Thus, the introduction of Doxorubicin leads to pronounced submicroscopic changes in the hemomicrocirculatory bed. Violation of the ultrastructural organization of the hemomicrocirculatory bed of the lungs is determined after 7 days after the start of the study.

Keywords: lungs, hemomicrocirculatory bed, Doxorubicin.

\section{Introduction}

Today, cancer is among the most common causes of death. Cancer ranks second after cardiovascular disease in the structure of mortality in Ukraine [17].

The analysis of the literature shows that chemotherapy occupies a significant place among the methods of treatment of malignant tumors $[6,14,18]$. The use of cytostatic therapy leads to improved immediate and long-term results of treatment of patients [19-21]. Most often in the treatment of cancer, anthracycline antibiotics are used, which are included in many cancer treatment regimens. To date, it has been proven that among the anthracycline antibiotics, Doxorubicin is one of the most effective anticancer drugs for the treatment of breast cancer, lymphomas, soft tissue sarcomas, leukemia, and some solid tumors [1, 4, 7, 20]. However, the antitumor effect of Doxorubicin directly correlates with the dose-dependent manifestation of toxicity to healthy tissues and body systems, which causes its adverse reactions [15, 22]. Most of the lethal cases in cancer patients do not occur due to the disease itself, but due to the side effects of anticancer drugs [9, 16]. 
It is known that the use of anthracycline antibiotic Doxorubicin in the treatment of malignant tumors in patients develops heart failure, which leads to the formation of Doxorubicin cardiomyopathy $[2,6,18]$.

But, in addition to cardiac injuries, there are also pronounced extra-cardiac changes of organs and systems. Pathological changes in the lungs, kidneys, liver, spleen and impaired function of the reproductive organs are most often observed [1, 3, 5, 8, 10].

The aim of this study was to study the dynamics of ultrastructural changes in the hemomicrocirculatory bed of the lungs under the influence of Doxorubicin.

\section{Materials and methods}

The experiments were performed on 70 white male rats weighing $180-220 \mathrm{~g}$. Animals were divided into 3 groups: I - intact group of animals $(n=10)$; II - control $(n=20)$; III animals with Doxorubicin model $(n=40)$.

Doxorubicin was administered intraperitoneally at a dose of $5 \mathrm{mg} / \mathrm{kg}$ body weight once a week for 4 weeks. An animal control group was intraperitoneally injected with an equivalent volume of saline.

Pulmonary tissue sampling for electron microscopic examination was performed under thiopental anesthesia 7 , $14,21,28$ days after the start of the experiment. Pieces of pulmonary tissue were fixed in $2.5 \%$ glutaraldehyde followed by fixation in $1 \%$ osmium tetroxide. After dehydration, the material was poured into araldite-epon. The sections obtained on a "Tesla BS-490" ultramicrotome were examined in an electron microscope "PEM-125K".

Retention, manipulation and withdrawal from the experiment were carried out in accordance with the requirements of the European Convention for the Protection of Vertebrate Animals Used for Research Purposes (Strasbourg, 1986), Council of Europe Directive 86/609/EEC (1986), the provisions of the Law of Ukraine "On the protection of animals from ill-treatment" dated 15.12.2009 and orders of the Ministry of Health of Ukraine № 690 dated September 23, 2009, № 616 dated August 3, 2012.

The Commission on Bioethics of the Ivano-Frankivsk National Medical University found that scientific research did not contradict basic bioethical standards (protocol № 96/17 of 24.05.2017).

\section{Results}

Conducted submicroscopic analysis after 7 days after the first injection of Doxorubicin showed that the nuclei of individual endothelial cells with a matrix of low electronoptical density and marginal placement of chromatin granules. The nuclear envelope has tortuous contours and produces shallow invaginations. Some mitochondria are enlarged in size with single crystae. Tanks and tubules of the Golgi apparatus and granular endoplasmic reticulum are moderately expanded. The basement membrane is locally thickened. In the peripheral departments of the endothelial cells there is a large number of micropinocytotic vesicles. In the lumen of some hemocapillaries, an increased amount of leukocytes with adhesion and aggregation is determined (Fig. 1).

With the increase of the study period (14 days after the first injection of Doxorubicin), the nucleus of many endothelial cells with nucleoplasm of low electron-optical density. Chromatin granules are placed along the inner surface of the nuclear envelope. Perinuclear region is moderately expanded. Mitochondria swollen with single short crystae. The Golgi apparatus consists of expanded tanks, various sizes of bubbles and vacuoles. In individual cells, fragmentation of membranes of the granular endoplasmic reticulum with a reduced number of ribosomes on their outer surface is noted. On the luminal surface of the plasmalemma of some endothelial cells, its sail projections are observed. The basement membrane is thickened in many places. In the lumen of the hemocapillaries, the aggregation and adhesion of leukocytes and platelets are noted.

Electron microscopic data from the 21st day indicate that the severity and prevalence of edema in endothelial cells is much greater than at the previous stage of the experiment. The nuclei of many endothelial cells with enlightened nucleoplasm. Mitochondria enlarged in volume with single fragmented crystae. At the same time, mitochondria with complete lysis of the crystae are noted, but without tearing of the outer membrane. The Golgi apparatus is represented by single extended tanks and vacuoles. Tanks of granular endoplasmic reticulum are expanded and vacuolated. The number of ribosomes on their outer surface is greatly reduced. Fragmentation of the membranes of the granular endoplasmic reticulum is also observed. In some hemocapillaries, the areas of lysis of the luminal plasmalemma of the endothelial cells are determined, accompanied by the release of intracellular contents into the lumen of the microvessels. In the lumen of many hemocapillaries, erythrocyte sludge, adhesion, and platelet aggregation are noted (Fig. 2).

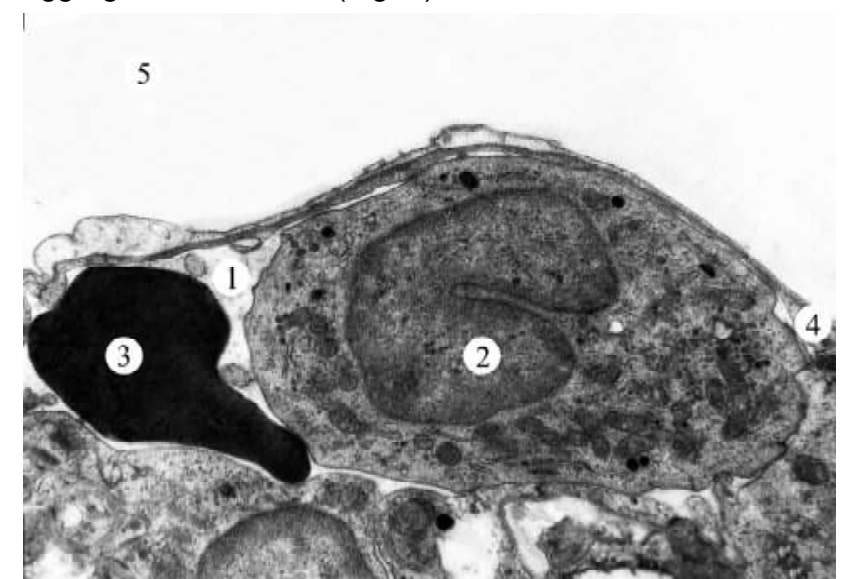

Fig. 1. Ultrastructural organization of the hemocapillaries of the alveoli wall 7 days after the start of the experiment. 1 - the lumen of the hemocapillary; 2 - leukocyte; 3 - erythrocyte; 4 - peripheral part of the endothelial cell; 5 - the lumen of the alveoli. Electronic micrograph. x6400. 


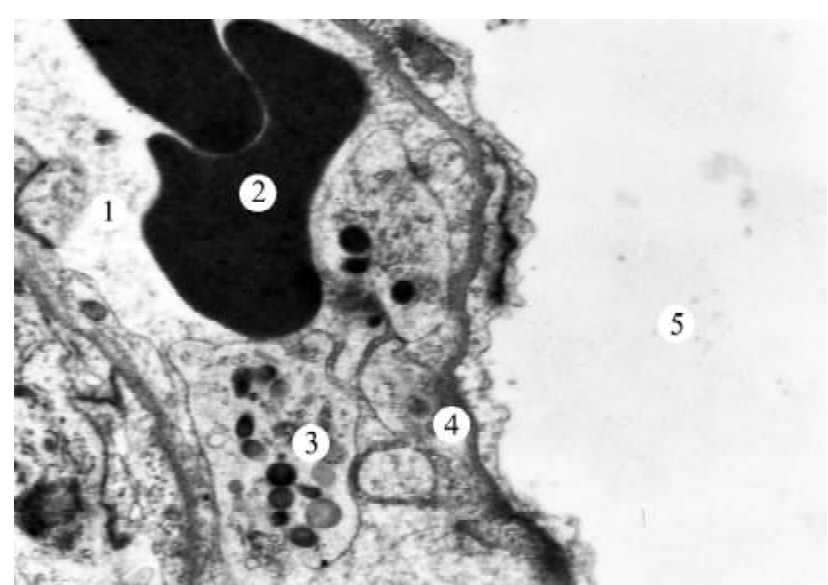

Fig. 2. Platelet adhesion and aggregation and erythrocyte sludge in the hemocapillaries of the alveolar wall 21 days after the start of the experiment. 1 - the lumen of the hemocapillary; 2 - erythrocyte; 3 - platelet; 4 - peripheral part of the endothelial cell; 5 - the lumen of the alveoli. Electronic micrograph. $\times 9600$.

The expressed disturbances of ultrastructural organization of hemocapillaries are determined after 28 days after the beginning of the experiment. Endothelial cell nuclei are enlarged in size with low electron-optical density nucleoplasm. Chromatin granules are placed along the inner surface of the nuclear membrane or grouped into separate tubercles. Perinuclear region is expanded. Mitochondria are swollen in various sizes and shapes with disoriented crystae. Focal destruction of the crystae, fragmentation and destruction of both the inner and outer membranes of the mitochondria are often noted. The components of the Golgi apparatus and the granular endoplasmic reticulum are enlarged, fragmented. In some areas, the desquamation of endothelial cells in the lumen of the hemocapillary with the basal membrane exposure is determined. Erythrocyte sludge and platelet aggregates are observed in the lumen of the hemocapillaries.

\section{Discussion}

Thus, studies have shown that within 7 days after the first injection of Doxorubicin in the lungs are determined changes in the structural organization of the hemomicrocapillary bed and impaired blood rheological properties, as evidenced by the excessive accumulation of neutrophils in the hemocapillaries, their adhesion and

\section{References}

[1] Bazykov, I. A., Beier, E. V., Lukynova, V. V., \& Maltsev, A. N. (2015). Comparative evaluation of the acute toxicity of Doxorubicin and its niosomal form. Medical Bulletin of the North Caucasus, 10(4(38)), 403-406.

[2] Chatterjee, K., Zhang, J., Honbo, N., \& Karliner, J. S. (2010). Doxorubicin cardiomyopathy. Cardiology, 115(2), 155-162. doi: $10.1159 / 000265166$

[3] Diamond, O. M., Turgeman, O., \& Blumenfeld, Z. (2015). Minimizing the Doxorubicin-Induced gonadotoxicity by sphingosine-1phosphate analogue FTY720. Am. J. Clin. Exp. Obstet. Gynecol., 2(1), 24-33. aggregation. With the extension of the study period (14-28 days) there is a progressive disturbance of the submicroscopic structure of hemocapillaries of the alveolar wall and marked changes in the rheological properties of blood. In endothelial cells, swelling phenomena with organ disorganization are determined, and in some areas there is a desquamation of endothelial cells into the lumen of the hemocapillaries with the basal membrane exposing. In the lumen of the microvessels, red blood cells and leuco-platelet aggregates are noted.

Changes of a similar nature in the lung tissue during the action of Doxorubicin are indicated by several other researchers $[13,15]$. The authors note the pronounced plethora of vessels with signs of stasis, sludge, thrombosis. In some places, the luminescence of the alveoli is almost undetermined by edema, atelectasis, in these parts of the lung parenchyma intensively infiltrated by polymorphonuclear leukocytes.

Doxorubicin is known to be able to induce oxidative stress in cells and directly damage the cytoplasmic membrane. Disruption of the functioning of cyto- and endoplasmic membranes is accompanied by an increase in their permeability. Particularly pronounced dystrophic-destructive changes are found in the mitochondria of cardiomyocytes. When the membranes of the lysosomes are damaged, proteolytic lysosomal enzymes are released into the cytosol, their destructive effect is exacerbated against the background of macroergic deficiency. In addition, there is a vacuolation and resorption of sarcoplasm and disruption of the nucleus structure [2, 11, 12]. Similar changes in the ultrastructural organization described by us in the endothelial cells of the hemocapillaries of the alveolar wall under the action of Doxorubicin.

The prospect of further development is the correction of ultrastructural changes in the hemomicrocirculatory bed of lungs under the action of Doxorubicin.

\section{Conclusions}

1. Studies have shown that the introduction of Doxorubicin leads to pronounced submicroscopic changes in the hemomicrocirculatory bed of the lungs.

2. Violation of the ultrastructural organization of the hemomicrocirculatory bed of the lungs is determined after 7 days after the start of the study.

[4] Fernandez-Chas, M., Curtis, M. J., \& Niederer, S. A. (2018). Mechanism of Doxorubicin cardiotoxicity evaluated by integrating multiple molecular effects into a biophysical model. British Journal of Pharmacology, 175(5), 763-781. doi: 10.1111/ bph.14104

[5] Haina, Zh. M., Kosuba, R. B., \& Yaremii, I. M. (2012). Corrective effect of mildronate on the performance of oxidant-antioxidant equilibrium in rats against toxic Doxorubicin. Medical Chemistry, 1(14), 56-59.

[6] He, H., Liu, C., Wu, Y., Zhang, X., Fan, J., \& Cao, Y. (2018). A multiscale physiologically-based pharmacokinetic model for 
Doxorubicin to explore its mechanisms of cytotoxicity and cardiotoxicity in human physiological contexts. Pharmaceutical research, 35(9), 174. doi: 10.1007/sl 1095-018-2456-8

[7] Hordiienko, Yu. A., Baklanova, Ya., Kovalenko, M. V., Stechenko, L. M., Shevtsova, A. I., \& Ushakova, G. O. (2012). Changes in physiological and biochemical parameters in rats with Doxorubicin-induced cardiopathy against the use of antioxidant drugs. Animal biology, 14(1-2), 74-79.

[8] Hozayen, W. G., Abou Seif, H. S., \& Amin, S. (2014). Protective effects of ruitn and/or hesperidin against Doxorubicin-induced hepatotoxicity. Int. J. Clin. Nutr., 2(1), 11-17. doi: 10.12691/ijcn2-1-2

[9] Kolotova, O. V., Fedorova, E. P., Ermolaeva, L. A., \& Churyn, A. A. (2008). The ability to correct the toxic effects of paclitaxel. Siberian Oncology Journal, (1), 66-68.

[10] Kobylinska, L. I., Havrylyuk, D. Y., Mitina, N. E., Zaichenko, A. S., Lesyk, R. B., Zimenkovsky, B. S., \& Stoika, R. S. (2016). Biochemical indicators of nephrotoxicity in blood serum of rats treated with novel 4-thiazolidinone derivatives or their complexes with polyethylene glycol-containing nanoscale polymeric carrier. The Ukrainian Biochemical Journal, 88(1), 51-60. doi: 10.15407/ubj88.01.051

[11] Linnyk, O. O., Drevytska, T. I., Tarasova, K. V., Portnichenko, G. V., Dosenko, V. E., \& Mankovska, I. M. (2016). Impairment of contractile activity of cardiomyocytes under the action of Doxorubicin. Physiological Journal, 6(62), 65-71.

[12] Linnyk, O. O., Honchar, O. O., Nosar, V. I., Drevytska, T. I., Kovalov, O. M., \& Mankovska, I. M. (2017). Effect of curcumin on mitochondrial function of cardiomyocytes in Doxorubicininduced oxidative stress. Physiological Journal, 1(63), 10-16.

[13] Luu, A. Z., Chowdhury, B., Al-Omran, M., Teoh, H., Hess, D. A., \& Verma, S. (2018). Role of endothelium in Doxorubicin-induced cardiomyopathy. JACC: Basic to Translational Science, 3(6), 861-870. doi: 10.1016/j.jacbts.2018.06.005

[14] McGowan, J. V., Chung, R., Maulik, A., Piotrowska, I., Walker, J.
M., \& Yellon, D. M. (2017). Anthracycline chemotherapy and cardiotoxicity. Cardiovascular Drugs and Therapy, 31(1), 6375. doi: 10.1007/sI0557-016-6711-0

[15] Pakryshen, S. V., \& Mokhort, M. A. (2013). Toxicodynamics of Doxorubicin (morphological study). Modern Problems of Toxicology, (1-2), 81-85.

[16] Ruggeri, C., Gioffré, S., Achilli, F., Colombo, G. I., \& D'Alessandra, Y. (2018). Role of microRNAs in Doxorubicin-induced cardiotoxicity: an overview of preclinical models and cancer patients. Heart Failure Reviews, 23(1), 109-122. doi: 10.1007/ s 10741 -017-9653-0

[17] Shchepotyn, I. (2013). What do we know about cancer? Pharmacist Practitioner, 2, 8.

[18] Shevchuk, O. O., Volska, A. S., Yaremchuk, O. Z., Kurylo, K. I., Bardakhivska, K. I., Nikolaev, V. G., \& Posokhova, K. A. (2019). Prooxidant-antioxidant balance in rats against subchronic Doxorubicin toxicity and the use of enterosorption and filgrastim (literature review and results of own studies). Medical and Clinical Chemistry, 3(21), 13-22. doi: 10.11603/mcch.2410681X.2019.v.i3.10555

[19] Shushanov, S. S., \& Kravtsova, T. A. (2013). In vitro cytotoxic effect of Doxorubicin on human multiple myeloma cells. Bulletin of Experimental Biology and Medicine, 155(2), 195-200.

[20] Todor, I. M., Lukianova, N. Yu., Tymovska, Yu. O., Pivniuk, V. M., \& Chekhun, V. F. (2013). Influence of Doxorubicin in liposomal form on tumors with phenotype of drug resistance. Oncology, 4(15), 279-285.

[21] Volkova, M., \& Russell, R. (2011). Anthracycline cardiotoxicity: prevalence, pathogenesis and treatment. Current Cardiology Reviews, 7(4), 214-220. doi: 10.2174/157340311799960645

[22] Zupanets, I. A., Vietrova, K. V., Sakharova, T. S., \& Torianik, E. L. (2013). Possibilities of correction of toxic effects of anticancer antibiotic Doxorubicin by derivatives of glucose mine and their combinations. Ukrainian Biopharmaceutical Journal, 4(27), 8792.

\section{УЛЬТРАСТРУКТУРНА ОРГАНІЗАЦІЯ ГЕМОМІКРОЦИРКУЛЯТОРНОГО РУСЛА ЛЕГЕНЬ ПІД ВПЛИВОМ ДОКСОРУБІЦИНУ Заяць Л.М., Янків О.О., Гунас І.В., Шаповал О.М., Шипіцина О.В.}

Одним із найефективніших протипухлинних препаратів, котрим лікують рак молочної залози, лімфоми, саркоми м'яких тканин, лейкемії, деякі солідні пухлини є доксорубіцин. Разом із тим, його протипухлинний ефект прямо корелює з дозозалежним проявом токсичності відносно здорових тканин і систем організму. Мета роботи - вивчити в динаміці ультраструктурні зміни гемомікроциркуляторного русла легень під впливом доксорубіцину. Тварини були розділені на 3 групи: I - інтактні щури (n=10); II - контрольна (n=20); III - щури з доксорубіциновою моделлю (n=40). Доксорубіцин вводили внутрішньоочеревинно у дозі 5 ма/ка маси тіла тварини 1 раз на тиждень впродовж 4 тижнів. Контрольній групі тварин внутрішньоочеревинно вводили еквівалентний об'єм фізіологічного розчину. Забір легеневої тканини для електронномікроскопічного дослідження проводили під тіопенталовим наркозом через 7, 14, 21, 28 діб після початку експерименту. Шматочки легеневої тканини фріксували у 2,5\% розчині глютаральдегіду з подальшою дофріксацією в $1 \%$ розчині чотириокису осмію. Після дегідратації матеріал заливали в епон-аралдіт. Зрізи, отримані на ультрамікротомі "Tеsla BS-490", вивчали в електронному мікроскопі "ПЕМ-125К". Встановлено, що вже через 7 діб після першого введення доксорубіцину в легенях визначаються зміни структурної організації гемомікрокапілярного русла і порушення реологічних властивостей крові, про що свідчить надмірна акумуляція нейтрофілів у гемокапілярах, їх адгезія та агрегація. Із продовженням терміну дослідження (14-28 діб) спостерігали прогресуюче порушення субмікроскопічної будови гемокапілярів альвеолярної стінки та виражені зміни реологічних властивостей крові. В ендотеліальних клітинах визначаються набрякові явища з дезорганізацією органел, а в окремих ділянках спостерігається десквамація ендотеліоцитів до просвіту гемокапілярів з оголенням базальної мембрани. У просвіті мікросудин відмічаються еритроцитарні сладжі й лейкотромбоцитарні агрегати. Таким чином, введення доксорубіцину призводить до виражених субмікроскопічних змін гемомікроциркуляторного русла легень. Порушення ультраструктурної організації гемомікроциркуляторного русла легень визначається вже через 7 діб після початку дослідження.

Ключові слова: легені, гемомікроциркуляторне русло, доксорубіцин.

\section{УЛЬТРАСТРУКТУРНАЯ ОРГАНИЗАЦИЯ ГЕМОМИКРОЦИРКУЛЯТОРНОГО РУСЛА ЛЕГКИХ ПОД ВОЗДЕЙСТВИЕМ ДОКСОРУБИЦИНА \\ Заяц Л.М., Янкив Е.О., Гунас И.В., Шаповал Е.Н., Шипицина А.В.}

Одним из наиболее эффрективных противоопухолевых препаратов, которым лечат рак молочной железы, лимфомы, саркомы 
мягких тканей, лейкемии, некоторые солидные опухоли является доксорубицин. Вместе с тем, его противоопухолевый эффрект прямо коррелирует с дозозависимым проявлением токсичности относительно здоровых тканей и систем организма. Цель работы - изучить в динамике ультраструктурные изменения гемомикроциркуляторного русла легких под влиянием доксорубицина. Животные были разделены на 3 группы: I - интактные крысы (n=10); II - контрольная ( $n=20) ;$ III - крысы $c$ доксорубициновой моделью $(n=40)$. Доксорубицин вводили внутрибрюшинно в дозе 5 мг/кг массы тела животного 1 раз в неделю в течение 4 недель. Контрольной группе животных внутрибрюшинно вводили эквивалентный объем фризиологического раствора. Забор легочной ткани для электронно-микроскопического исследования проводили под тиопенталовым наркозом через 7, 14, 21, 28 суток после начала эксперимента. Кусочки легочной ткани фиксировали в 2,5\% растворе глютаральдегида с последующей дофиксацией в 1\% растворе четырехокиси осмия. После дегидратации материал заливали в эпон-аралдит. Срезы, полученные на ультрамикротоме "Tesla BS-490" изучали в электронном микроскопе "ПЭМ-125К". Установлено, что уже через 7 суток после первого введения доксорубицина в легких определяются изменения структурной организации гемомикрокапиллярного русла и нарушение реологических свойств крови, о чем свидетельствует чрезмерная аккумуляция нейтрофилов в гемокапиллярах, их адгезия и агрегация. С продлением срока исследования (14-28 суток) наблюдали прогрессирующее нарушение субмикроскопической строения гемокапилляров альвеолярной стенки и выраженные изменения реологических свойств крови. В эндотелиальных клетках определяются отечные явления с дезорганизацией органелл, а в отдельных участках наблюдается десквамация эндотелиоцитов в просвет гемокапилляров с обнажением базальной мембраны. В просвете микрососудов отмечаются эритроцитарные сладжы и лейкотромбоцитарные агрегаты. Таким образом, введение доксорубицина приводит к выраженным субмикроскопическим изменениям гемомикроциркуляторного русла легких. Нарушение ультраструктурной организации гемомикроциркуляторного русла легких определяется уже через 7 суток после начала исследования.

Ключевые слова: легкие, гемомикроциркуляторное русло, доксорубицин. 